\title{
Exploration on the Successful Experience of Disaster Avoidance from Mountain Torrents Disaster in Xiaodianwu, Kecheng District
}

\author{
Lihong ZHANG ${ }^{\text {a,1 }}$, Hanze LI ${ }^{\text {a }}$, zhengjie ZHOU ${ }^{\text {a }}$, Hongri ZHENG ${ }^{\text {a }}$, Lu ZHANG ${ }^{\text {a }}$ and \\ Qian $\mathrm{LI}^{\mathrm{a}}$ \\ ${ }^{a}$ Zhejiang Institute of Hydraulics and Estuary, Zhejiang Provincial Key Laboratory of \\ Hydraulic Disaster Prevention and Mitigation,Hangzhou,Zhejiang 31000, China
}

\begin{abstract}
Mountain torrents disasters have become one of the main types of natural disasters in the world and causes a large number of casualties and economic losses. The construction of mountain torrents disaster mass monitoring and prevention system is an important part of mountain torrents disaster prevention and control construction in China. This paper introduces the main contents of the mass monitoring and prevention system, investigates the causes of mountain torrents disasters in Xiaodianwu, Kecheng District, analyzes the function of the forecasting and early warning measures, explores the successful experience of disaster avoidance, and provides reference for the improvement of mountain torrents disaster defense capabilities. In the process of defensing the mountain torrents disasters in Xiaodianwu, the village-level inspectors carried out on-site inspections in the rain and immediately organized door-to-door warnings and personnel transfers after discovering the danger, gaining valuable time for the successful avoidance of danger. The effective connection and close cooperation of the work chain at the provincial, city, county, and village levels were the key to the successful avoidance of this mountain torrent disaster.
\end{abstract}

Keywords. Mountain torrents disaster, forecasting and early warning measures

\section{Introduction}

\subsection{Mountain Torrents Disasters}

Mountain torrents disasters refer to river torrentss caused by heavy rainfall in a small area (usually within a few hundred square kilometers) of hilly areas, as well as mudslides, landslides and other disasters induced by river torrentss, which has characters of occurred suddenly, causing large harm, governed difficultly and is difficult to predict. Mountain torrents disasters have become one of the main types of natural disasters in the world, causing a large number of casualties and economic losses [1-2].

\footnotetext{
${ }^{1}$ Lihong Zhang, Zhejiang Institute of Hydraulics and Estuary, Zhejiang Provincial Key Laboratory of Hydraulic Disaster Prevention and Mitigation, Hangzhou, Zhejiang 31000, China; E-mail: 984271320@qq.com.
} 


\subsection{Mass Monitoring and Prevention}

The basic meaning of mass monitoring and prevention is to carry out mass disaster prediction and prevention, and it is an effective disaster prevention means to adapt to the current national conditions of our country [3]. From earthquake disaster to mountain torrents \& geological disaster, mass monitoring and prevention have played an important role in the prevention and control of various natural disasters in China. Mountain torrents disaster's mass monitoring and prevention refers to the people's governments at the county (city, district) and township (town) levels and village (residents) committees in the mountain torrents disaster prevention and control area, organize enterprises and institutions and the broad masses of the people within their jurisdiction, and, under the guidance of the water administrative department and relevant professional and technical units, establish defense organizations, implement the responsibility system, prepare disaster prevention plans, publicize disaster prevention knowledge by means of risk avoidance skills training, disaster avoidance measures drilling and other means, we can monitor and warn against sudden disasters such as torrentss caused by rainfall, so as to realize an active disaster prevention and reduction system for early prevention, timely monitoring, rapid warning and effective avoidance of mountain torrents [3-4]. Carrying out mountain torrents disaster mass monitoring and prevention is an important means suitable for China's national conditions and effective prevention of mountain torrents disasters. The practice of mountain torrents prevention and control for more than 10 years has also proved that mass monitoring and prevention is an important part of mountain torrents disaster prevention system in China. Especially in the case of communication and power interruption caused by mountain torrents or difficult coverage of professional monitoring and early warning systems, the mass monitoring and prevention system organizes the masses to avoid risks spontaneously, effectively reduced casualties and property losses, and plays a significant benefit of disaster prevention and reduction in the practice of mountain torrents disaster prevention [5-6].

The characteristics of mountain torrents disaster in China determine that county, township and village at the grass-roots level are the front and main battlefield of mountain torrents disaster prevention. Therefore, how to give full play to the strength of grass-roots rural organizations and villagers themselves is the key to do well in the prevention of mountain torrents disaster [7]. Since 2002, the top level design of mountain torrents disaster has been paying great attention to the construction of group survey and group prevention system, which is an important part of the system of mountain torrents disaster prevention in China. Group survey and group prevention and professional monitoring and early warning system complement each other, and can not be complemented and play a role together. The combination of professional monitoring and warning system and group monitoring and group prevention system has been one of the main concepts of coping with mountain torrents disasters in China [6].

According to the development of more than 10 years, mass monitoring and prevention of mountain torrents in China has formed a relatively mature system. Generally speaking, the mountain torrents disaster mass monitoring and prevention system includes responsibility system, defense plan, monitoring and early warning, publicity, training and drill [8]. In 2015, the Office of the National Torrents control and Drought Relief Headquarters organized and formulated the guiding opinions on the construction of mountain torrents disaster mass monitoring and prevention system to 
standardize and guide all localities to carry out the construction of group survey and prevention system. Its main contents include:

(1) Construction of responsibility system. According to the Administration Chief Responsibility System, we will establish an insurance responsibility system in which The county is responsible for the township, the township is responsible for the village, the village is responsible for the group, and the cadres and Party members are responsible for the masses, so as to realize grid management; The defense work shall be uniformly led and organized by the County torrents control and Drought Relief Department, and the township (town) shall establish corresponding institutions; Counties, townships (towns) shall set up corresponding working groups according to the needs of defense work; The administrative village shall set up a working group to implement the monitoring of rainfall and water level, early warning release, personnel transfer and other work; The scenic spots and industrial and mining enterprises in the mountain torrents disaster prevention and control area shall implement the mountain torrents prevention responsibility.

(2) Defense plan. Prepare mountain torrents disaster prevention plans at county (city, district), township (town) and administrative village levels and revise them in time; The county-level plan shall be approved and published by the people's government at the county level and reported to the institution at the next higher level for the record; The township (town) level and village level shall be approved and published by the township (town) level people's government and reported to the county-level organization for the record; Township (town) and village level plans shall be concise and easy to operate, focusing on the organization, personnel and responsibilities, early warning signals, scope and personnel of the dangerous area, transfer route, etc., and the map of mountain torrents disaster dangerous area shall be attached.

(3) Monitoring and early warning. Simple rainfall alarms are arranged in townships (towns), administrative villages and key natural villages; Simple water level stations are arranged in villages along the river, which can increase the automatic alarm function; Villages equipped with rainfall and water level monitoring facilities shall also be equipped with facilities and equipment for issuing early warning information; In case of rainstorm weather forecast, organize and make preparations for mountain torrent prevention in advance; Release early warning information quickly when the monitored rainfall or water level reaches the early warning index; In torrents season, warning signs and broadcasts shall be set up in tourist attractions and construction sites to remind tourists and construction personnel to pay attention to mountain torrents.

(4) Publicity, training and drill. Arrange billboards, posters, billboards, slogans and other publicity materials in appropriate parts; Set up signboards and signs at eyecatching positions in hazardous areas; Clear cards are issued to households in flash torrents hazard areas; Carry out defense knowledge publicity in various forms and strengthen the publicity and education of primary and middle school students; Regularly hold training and carry out comprehensive drills.

Generally speaking, the construction scope of mountain torrents disaster group measurement and prevention system involves counties, townships (towns) and villages, with the focus on villages. The administrative villages in the mountain torrents disaster prevention and control area shall build a group measurement and prevention system according to the "ten ones", that is, establish a set of responsibility system, prepare a defense plan, install at least one simple rainfall alarm (appropriately increased in key areas), configure a set of early warning equipment (key administrative villages are 
equipped with a set of wireless early warning broadcasting), make a billboard, and organize training once a year One drill shall be carried out, one temporary refuge point shall be determined in each dangerous area, one set of warning signs shall be set, and one clear card (including publicity manual) shall be issued to each household.

\subsection{Brief Introduction on the Mountain Torrents and Mudslide Disaster in Xiaodianwu}

Xiaodianwu of Dahou village in Kecheng district is located in the section of Dahou village in miaoyuan River, Kecheng district. The water level of the river rises and falls sharply in a torrents, and the village is located in a hilly area with steep surrounding mountains and many potential geological hazards.

During the Meiyu period in 2020, Kecheng District experienced a total of seven rounds of heavy rainfall. Relying on the "triple project", and under the overall coordination, accurate prediction and timely rescue of the torrents and drought control headquarters of Kecheng District, more than 3200 people were transferred and resettled and 7 farmers and 150 children were rescued in the whole Meiyu period.

At about 00:00 a.m. on June 4, village cadres and village duty officers in Dahou village of Jiuhua Township found that the road was muddy with rain. After reporting the abnormal situation, the village immediately organized forces to dredge and transfer the masses. At 00:26, mountain torrent and mudslide disaster occurred in xiaodianwu, where 10 households and 29 people at home before. In the "6.4" Mountain torrent and mudslide disaster in xiaodianwu, Dahou village, Jiuhua, casualties were successfully avoided and no one was injured.

\section{Analysis of Disaster Causing Factors}

\subsection{Rainfall}

After entering the plum on May 29th, two rounds of heavy rainfall began to occur in the night from 29th to June 2nd. The surface rainfall in Quzhou reached 239mm, of which the surface rainfall in Kecheng District was $246 \mathrm{~mm}$. The maximum accumulated rainfall is $376 \mathrm{~mm}$ at Zhangxi Station. The continuous heavy rainfall caused the water level of small river basins such as Dajuyuan, Shiliangxi and Miaoyuanxi in Kecheng District to soar.

According to the monitoring data of Dahou Rainfall Station,which in Xiaodianwu Village 1.6km downstream. The first round of rainfall was from 19:00 on May 29th to 18:00 on May 30th, and the rainfall was relatively small. The second round of rainfall was from 19:00 on June 2nd to14:00 on June 4th. and lasted 43 hours. The rainfall at Dahou Station reached $225.5 \mathrm{~mm}$, and the maximum 1 hour rainfall was $33.5 \mathrm{~mm}$ (at 23:00 on June 3), the maximum 3 hours rainfall was $57 \mathrm{~mm}$ (from 21:00 to 23:00 on June 3), and the maximum 6 hours rainfall was $68 \mathrm{~mm}$ (from 18:00 to 23:00 on June 3).

In order to analyze the recurrence period of the rainstorm in Xiaodianwu, the rainstorm atlas method was selected to calculate the design rainstorm using Dahou Station.

By looking the average point rainfall and the variation coefficient $\mathrm{Cv}$ of each duration at Dahou station according to the mean point rainfall contour map and the point rainfall variation coefficient contour map of Zhejiang Province's short-duration rainstorm atlas, we calculated the design rainstorm for each duration. 
The calculation results are shown in table 1.

Table 1. Design Rainstorm Results of Dahou Station.

\begin{tabular}{|c|c|c|c|c|c|c|c|c|c|}
\hline \multirow[b]{2}{*}{$\begin{array}{l}\text { Station } \\
\text { name }\end{array}$} & \multirow[b]{2}{*}{ Duration } & \multirow{2}{*}{\multicolumn{2}{|c|}{$\begin{array}{ll}\text { average } & \text { the } \\
\text { point } & \text { variation } \\
\text { rainfall } & \text { coefficient } \\
(\mathrm{H}) & (\mathrm{Cv}) \\
\end{array}$}} & \multicolumn{5}{|c|}{ recurrence interval of rainfall $(\mathrm{Hp})$} & \multirow[b]{2}{*}{$\begin{array}{l}5 \text { year } \\
(\mathrm{H} 20 \%)\end{array}$} \\
\hline & & & & $\mathrm{Cs} / \mathrm{Cv}$ & $\begin{array}{l}100 \text { year } \\
(\mathrm{H} 1 \%)\end{array}$ & $\begin{array}{l}50 \text { year } \\
(\mathrm{H} 2 \%)\end{array}$ & $\begin{array}{l}20 \text { year } \\
\text { (H5\%) }\end{array}$ & $\begin{array}{l}10 \text { year } \\
(\mathrm{H} 10 \%)\end{array}$ & \\
\hline \multirow{4}{*}{$\begin{array}{l}\text { Dahou } \\
\text { station }\end{array}$} & $60 \mathrm{~min}$ & 40.0 & 0.42 & 3.5 & 96 & 86 & 73 & 62 & 52 \\
\hline & $3 \mathrm{~h}$ & / & / & / & 135 & 121 & 102 & 87 & 72 \\
\hline & $6 \mathrm{~h}$ & 68.0 & 0.44 & 3.5 & 168 & 151 & 127 & 108 & 88 \\
\hline & $24 \mathrm{~h}$ & 110 & 0.48 & 3.5 & 282 & 251 & 209 & 177 & 144 \\
\hline
\end{tabular}

According to the calculated design rainstorm results, the recurrence period of the heavy rain at Dahou Station during the current rainfall period is analyzed, and the results are shown in table 2.

Table 2. Analysis results of the return period of heavy rain at Dahou Station.

\begin{tabular}{llll}
\hline Station name & Duration & Rainfall $(\mathbf{m m})$ & Return period \\
\hline \multirow{3}{*}{ Dahou station } & $1 \mathrm{~h}$ & 33.5 & Less than once in 5 years \\
& $3 \mathrm{~h}$ & 57.0 & Less than once in 5 years \\
& $6 \mathrm{~h}$ & 68.0 & Less than once in 5 years \\
& $24 \mathrm{~h}$ & 150.0 & once in 5 years \\
\hline
\end{tabular}

From the analysis of the return period of the heavy rain at Dahou Station, the 24hour rainfall of this heavy rainfall was slightly larger than the design rainstorm of once in 5 years.

\subsection{Analysis of Disaster Pregnant Environment}

Townships such as Jiuhua, Shiliang, and Qili in Kecheng District are areas prone to geological disasters, especially in Jiuhua where large mudslides have occurred before, the rainfall lasted for a long time (from May 29 to June 4). and the rain intensity is relatively large (the process rainfall reached $225.5 \mathrm{~mm}$ ), which all could easily cause natural disasters such as mountain torrents and mudslides in small watersheds. Moreover, according to the on-site investigations, the steepness of the Xiaodianwu mountain is about 40 degrees, and road construction caused the mountain to loosen, which made it more prone to debris flow.

\section{Early Warning, Mass Monitoring and Preventing}

Based on meteorological numerical forecasts, the Water Resources Department of Zhejiang Province considers that the soil water content in the early stage is basically saturated, which can easily cause mountain torrent geological disasters. The fifth-phase flash torrents warning fax was issued at 19:00 on June 2 to issue a yellow flash torrents warning to Kecheng District in the next 24 hours. On the afternoon of the 3rd, the Provincial Hydrological Center and the Quzhou Hydrological Center conducted a telephone conference to specifically conduct risk on mountain torrent disasters. They 
believed that although there were no warning signals on the provincial platform, there were greater risks of mountain torrents in Quzhou Kaihua, Jiangshan, Changshan, Kecheng and other places, and they recommended that Quzhou provide early warnings of mountain torrents to relevant counties.

The Quzhou City Hydrology, Torrents and Drought Disaster Prevention Center issued a mountain torrent warning fax at 18:00 on the 3rd, which noted that from 20:00 on the 3rd to 20:00 on the 4th, the northern part of Kecheng District will have an orange warning for mountain torrent disasters. The Kecheng District Water Conservancy Bureau forwarded the forecast and early warning information to the district defense indicator in a timely manner, and assigned personnel to follow the Kecheng Mountain Torrents Disaster Monitoring and Early Warning Platform 24 hours a day, and pay close attention to real-time rain and water regime information. At 23:22 on June 3, the Kecheng Mountain Torrents Disaster Monitoring and Early Warning Platform issued in time "[Quzhou Kecheng Water Conservancy Bureau] [Warning Information] Rainfall Red Warning: Dahou Station June 02, 23:15 to June 03, 23:15 the accumulated rainfall in 24 hours was $150.0 \mathrm{~mm}$ ". The cadres and village duty officers of Dahou Village, Jiuhua Township received the actual warning message sent by the Kecheng Mountain Torrents Monitoring and Early Warning Platform, and they immediately carried out on-site inspections. At around 00:00 on June 4, they found that the road was muddy with rain, and after reporting the abnormal situation, the village immediately organized forces to divert and transfer the masses. At 00:26, a mudslide occurred in Xiaodianwu, all resettlement was completed before the incident.

From May 29th to June 4th, the Kecheng Mountain Torrents Disaster Monitoring and Early Warning System Platform issued a total of 14,427 early warning messages. Through the early warning and forecast of water and rain conditions, it provided strong support for the prevention of torrentss and droughts in the region and avoiding casualties.

Due to proper handling and timely transfer and rescue, 29 people from 10 houses in 10 buildings were transferred 10 minutes before the arrival of the mudslide. There were no casualties in the mudslide disaster caused by the heavy rainfall. In order to prevent secondary disasters, 107 people in the possible dangerous area of the landslide site and the surrounding area had been moved to safety at 3:30 on June 4th. At 17:00 on June 4, all 395 people in the village were safely transferred and resettled.

\section{Conclusions}

Townships such as Jiuhua, Shiliang, and Qili in Kecheng District are areas prone to geological disasters, especially in Jiuhua where large mudslides had occurred before, and this rainfall lasted for a long time (from May 29 to June 4). The rain intensity is relatively large (the process rainfall reaches $225.5 \mathrm{~mm}$ ), which could easily cause natural disasters such as mountain torrents and mudslides in small watersheds. According to on-site investigations, the steepness of the Xiaodianwu mountain is about 40 degrees, and road construction caused the mountain to loosen, which made it more prone to debris flow.

After the flash torrents forecast and early warning information issued, the Kecheng Water Resources Bureau's on-duty staff closely monitored the changes in water levels and rain conditions, the district-level flash torrents monitoring and early warning platform was operating normally, and the measured early warning messages were sent 
in time and effectively alerted the village-level inspectors. The village-level inspectors carried out on-site inspections in the rain and immediately organized door-to-door warnings and personnel transfers after discovering the danger, gaining valuable time for the successful avoidance of danger. The effective connection and close cooperation of the work chain at the provincial, city, county, and village levels were the key to the successful avoidance of this mountain torrent disaster.

\section{References}

[1] Li HX, Qin GH, Wang X, et al. Research progress of mountain torrent forecasting and early warning technology. Journal of China Hydrology, 2014 Oct; 34(5): 12-16.

[2] Liu ZY, Yang DW, Hu JW. Small and medium river flood warning method based on dynamic critical rainfall and its application. Journal of Beijing Normal University (Natural Science Edition), 2010 Nov; 46(3): 317-321.

[3] He BS, Huang XL, Ma MH. Thoughts on further doing the mass monitoring and prevention of mountain flood disasters. China Flood \& Drought Management. 2015 Aug; 25(6): 61-64.

[4] He BS, Guo L, Xu J. Discussion on the mass monitoring and prevention model of mountain flood disasters in my country. China Water Resources, 2017 Oct; (20): 26-30, 50.

[5] Qiu RT. Construction progress and effectiveness of county-level non-engineering measures for mountain flood disaster prevention and control. China Water Resources, 2012 (23): 7-9.

[6] Guo L, Yang Zhaohui. Building a scientific defense system to actively respond to mountain torrent disasters. China Water Resources News, 2018 Jan; (005).

[7] Lu JH. Group monitoring and prevention is the key to preventing mountain flood disasters. China Water Resources, 2007; (14): 10-11.

[8] He BS, Chang JR, Chu MH. Discussion on the construction of mountain flood disaster prevention group monitoring and prevention system. China Water Resources, 2012 (13): 44-46. 